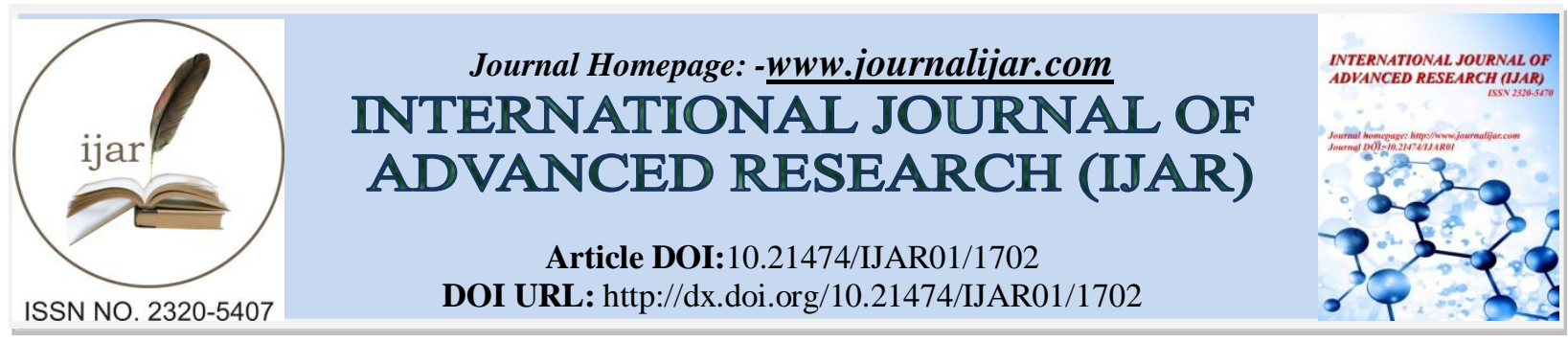

RESEARCH ARTICLE

\title{
INDIAN E-COMMERCE SECTOR - WILL IT BE EVOKED IN THE LIGHT OF GST?
}

Jomsy Thomas ${ }^{1}$, Radhika V $\mathbf{R}^{1}$ and Anna Celine $\mathbf{E} \mathbf{J}^{2}$.

1. Assistant Professor, Department of Commerce (S/F), St.Xavier's College for Women, Aluva.

2. Research Scholar, Department of Commerce, St.Xavier's College for Women, Aluva.

\section{Manuscript Info}

Manuscript History

Received: 12 July 2016

Final Accepted: 16 August 2016

Published: September 2016

Key words:-

E- Commerce, Taxman, GST,

Information technology, Indirect

Taxation

\section{Abstract}

E- Commerce industries are growing day by day as the web expansion by the Information Technology. E-Com industries can turn even one's bedroom as a shopping mall without any delay. Do such a magical business contributing to the revenue pool as they supposed to be? Now in India the taxman may make a really disappointing node for this question. But the GST implementation will allow the taxman of the country to take a relief breath, as great many issues of E- com Taxation will vanish thereby. This paper is a very humble effort to go through the loopholes used by E-Com companies of existing indirect taxation practices and how the problems are addressed in GST.

Copy Right, IJAR, 2016,. All rights reserved.

\section{Introduction:-}

Being people moved towards the field of wireless communication, anytime, every time shopping became very popular now a days. Due to the emergence of globalization and technological explosions happened in this era, people envisaged the power to shop from the showcases of companies located millions of miles apart from them. That too with his finger tip. This is the magic of E-Commerce. E - Buying and selling attaining its galloping momentum in these days. The world wide access with minimum cost made E- commerce a real hero in the retail sector of India. In the year 2007 the total market size of e-commerce in India was to the tune of Rs. $8146 \mathrm{Cr}$. This market has risen from Rs. 8146 Cr. in 2007 to nearly double a year later i.e. Rs. 14030 Cr. in 2008 to Rs. $46520 \mathrm{Cr}$ in 2011 which is $471.08 \%$ growth in just 4 years.*

It is obviously good news for the taxman of a country that such a big deal is going in and around as it will generate revenue and economic growth as well. 'Transferring my cash to your pocket' is always opening a window of wealth creation in an economy. But in the earlier period, when E- commerce put its baby steps in India, it was a hot discussion that whether the E- Commerce industry must be exempted from tax. In the 1997 International Fiscal Association ("IFA") Congress held at Delhi, David R Tillinghast, the Chairman of the Permanent Scientific Committee of the IFA rejected the suggestion for tax exemption on the ground that in e-commerce 'the margins are high and base is big'.** But addressing a 'super growing' industry with effective tax policy is real challenge for the authorities. A thorough planning with well-equipped tools for maintaining an optimum tax policy is a big deal for the concerned authorities. Even though E- commerce is predicted to be the next best industry in this era it must be unfortunate to accept that the taxation policies followed in India for E-commerce sector is not really played the role of a vigilant treasure hunter.

As a magic stick which can easily resolve the existing problems of taxation in Indian E commerce industry, India is at the threshold of its ever renowned tax reform - the GST (Goods and Services Tax). All the major problems faced 
by the existing indirect tax regime are well addressed in the proposed tax plan. Goods and Service Tax is expected to enlighten the dark side of the present taxation practices and also GST can be a key which can unlock the major confusion in the E-commerce taxation policies yet now.

\section{Objectives of the study:-}

* To analyze the present taxation on E-Commerce

* To study the impact of GST on E-commerce

* To analyze how implementation of GST will overcome the current taxation problems

\section{Research methodology:-}

The study is descriptive in nature. The data for the paper is based on various research papers, articles published and also from official websites of e-commerce companies and government of India.

\section{Niches of existing tax practices on E-Commerce in India:- Differentiated models of E-Commerce:-}

The e-commerce sector is characterized by the existence of different e-commerce models such as aggregator model, brokerage model, info-mediary model, value chain model, advertising model, utility model etc. which poses a threat before the indirect tax laws to recognize the evolving business models and charge tax accordingly.

\section{Difficulty in the categorization of Goods and Services:-}

In these days of advanced trade and technological improvisations differentiating goods and services became a herculean task for even the policy makers. This issue turns out as a loophole for the tax payers to evade tax. As per the present system VAT and CST is charged for goods and service tax for services. For instance it became a real difficulty if you need to go for the traditional classification of goods and services in the case of digital downloads involving software, music, e- books etc. Both VAT and Service tax authorities can claw their clutch on the tax payers in such situation. This can lead to a never ending litigation.

\section{Red tapism in interstate border:-}

When the goods need to be passed though the borders of different states the variation in the sales tax rules and other laws may become a nightmare for the operators. The various interstate transactions are red taped in the requirements of statutory formalities of state government, way- bill, road permits etc.

Site of sale of intangible goods:-

It is easy to locate the site of tangible goods, whereas in case of sale of intangible goods such as patents, copyrights, software etc., it is difficult to locate the exact place of sale. In such a case the location of sites for the seller become an unresolved problem for appropriating the state eligible for levying VAT.

\section{Absence of clarity in definitions;-}

The current federal indirect tax structure regarding e-commerce has laid down ways for various confusions and uncertainties. Lack of clear cut and the lack of well-defined laws had made the situation worse.Also the existing tax laws in India have failed to define typical e-commerce sector transactions like e-wallet (advance deposits by consumers), cash-on-delivery (payment collected at the door-step of the consumer), gift vouchers, drop-shipment etc.

Abundant number of E- Commerce business operator:-

There are a number of registered and unregistered e-commerce business operators in the market and they are growing supernaturally. Thesecompanies are making a millions of transactions even in a month. So in the existing practice of taxation there is enormous number of tax evasion practices.

\section{Impact of GST on E-commerce:-}

The on-going economic recession and slow down of economy across the world has given India a golden opportunity to get a better place in the world economy. To achieve this, India has to increase its GDP and restructure its financial policies. A major reform is to be brought in the tax structure which is, at present, complex, inefficient and nontransparent. The introduction of Goods and Services Tax (GST) will rationalize it and remove the loopholes in the present system. GST is anticipated to replace the existing multiple tax structures of Centre and State taxes which is 
not only desirable but imperative in the emerging economic environment. GST has been envisaged as a more efficient tax system, neutral in its application and compatible with India's federal structure.

\section{Benefits of GST over the present taxation policy on E-commerce:- Mitigation of cascading taxation:-}

Since under the GST regime, credit will be available across the entire supply chain there will be no cascading of taxes and the issues under the existing system like tax payable on tax will be suitably addressed.

\section{Elimination of multiple taxes and double taxation:-}

GST will subsume majority of existing indirect tax levies both at central and state level into one tax. This will make doing business easier and will also tackle the highly disputed issues relating to double taxation of a transaction as both goods and services.

\section{Increase in tax compliance and tax revenues:-}

As GST will do away with multiplicity of taxes, it will ensure a simpler tax regime with fewer taxes, rates and exemptions. A simplified tax regime coupled with simple, articulate and largely online procedures will lead to improved tax compliances with lesser scope for mistakes. Increased compliances together with a wider tax base will eventually boost the tax revenues on account of e-commerce transactions.

\section{Bringing clarity in taxation:-}

GST clearly defines various business terminologies, locations of transactions, tax payment system etc.

\section{Conclusion:-}

E- Com industries will be turning to become one of the pillars of the economy of India. Business can flourish well in a tax conductive environment. The e-com sector, as its business is anytime and every time, made the indirect taxation a big question. Present proposals in GST can be a magical weapon to address the major issues hidden in this sector. The model draft GST law lies to rest confusions and uncertainties in the present taxation system and provides clear cut definitions and clarity on valuation, place of supply, point of taxation etc. Let us hope that the darkened area of revenue collection may enlighten in the limelight of GST sooner.

\section{References:-}

1. http://www.ey.com/IN/en/Newsroom/News-releases/EY-gst-could-be-key-to-unlock-issues-faced-by-ecommerce-sector

2. http://www.thehindu.com/business/Economy/ecommerce-transactions-in-gst-net

3. http://www.business-standard.com/article/companies/gst-to-benefit-e-commerce-the-most114121900196_1.html/article8728976.ece

4. https://www.quora.com/What-will-be-the-impact-of-GST-on-e-commerce-industry

5. https://yourstory.com/2016/07/e-commerce-gst-flipkart-amazon-iamai/

6. http://www.myonlineca.in/legal-adda-powered-by-myonlineca/state-vat-cst-on-ecommerce 